\title{
Kualitas Telur Puyuh Selama Penyimpanan dan Temperatur yang Berbeda
}

\section{The Quality of Quail Egg on Different Storage Time and Temperature}

\section{Rizki Arizona* dan Abdul Rahman Ollong}

Laboratorium Produksi Ternak Fakultas Peternakan Universitas Papua, Jl.Gunung Salju, Amban, Manokwari Papua Barat, 98314

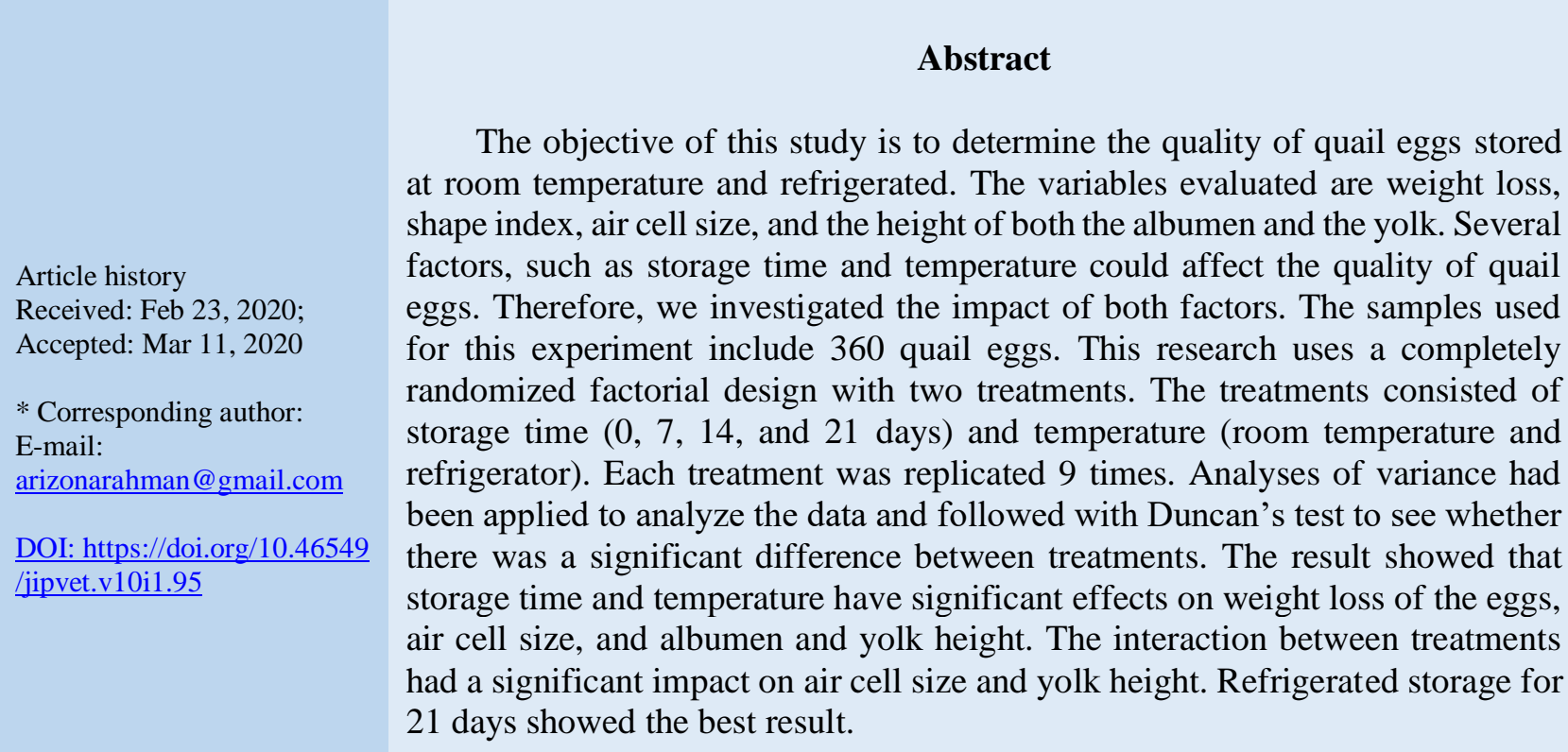

Keywords: Quality of albumen and yolk; Quail egg; Storage time; Temperature

\section{PENDAHULUAN}

Puyuh merupakan salah satu jenis unggas yang memiliki kemampuan bertumbuh dan berkembang biak secara cepat. Burung puyuh dapat memproduksi telur sekitar 250-300 butir/ekor/tahun (Nataamijaya, 2004). Penelitian Zurahmah (2010) puncak produksi telur burung puyuh pada umur 10 minggu. Nilai gizi telur puyuh hampir sama dengan telur unggas lain, sehingga dapat menambah variasi dalam penyediaan sumber protein hewani. Listyowati (2009) menyatakan bahwa kandungan protein telur puyuh sekitar1 3,1\% dan lemak $11,1 \%$. Persentase komponen telur yaitu kerabang dan membran $20,7 \%$, yolk $31,9 \%$ dan albumen $47,4 \%$.

Lama penyimpanan dan temperatur sangatlah menentukan kualitas telur puyuh. Semakin lama penyimpanan, maka berdampak pada kualitas telur yang semakin menurun. Penurunan kualitas meliputi bobot telur, kekentalan albumen dan kuning telur serta besarnya rongga udara. Fitrah et al. (2018) melaporkan penyimpanan selama 6 hari pada suhu $25-30^{\circ} \mathrm{C}$ tidak mempengaruhi penyusutan berat telur puyuh. Djaelani (2016) melaporkan telur puyuh yang disimpan selama 17 hari pada suhu ruang maka kandungan lemak dan indeks kuning telur semakin menurun. Belum ada informasi mengenai perbandingan perubahan kualitas telur puyuh selama penyimpanan pada temperatur refrigerator maupun suhu ruang.

Berdasarkan uraian diatas maka dilakukan penelitian tentang kualitas telur puyuh selama penyimpanan dan temperatur yang berbeda. Penelitian ini bertujuan untuk mengevaluasi kualitas telur berdasarkan penurunan berat telur, indeks bentuk telur, rongga udara, tinggi albumen dan yolk.

\section{MATERI DAN METODE}

\section{MATERI PENELITIAN}

Telur yang digunakan dalam penelitian ini adalah telur puyuh segar yang berumur 1 hari sebanyak 360 butir yang berasal dari satu peternak telur puyuh. Sebelum disimpan telur 
dibersihkan terlebih dahulu dengan tissue basah dan disimpan pada suhu ruang dan refrigerator kulkas.

\section{METODE}

Penelitian ini menggunakan Rancangan Acak Lengkap pola faktorial. Faktor lama penyimpanan $(0,7,14$ dan 21 hari) dan faktor temperatur (refrigerator dan suhu ruang) dengan ulangan sebanyak 9. Tiap ulangan menggunakan 5 butir telur. Variabel yang diamati adalah penurunan berat telur, indeks bentuk telur, rongga udara, tinggi albumen dan tinggi yolk.

Penurunan berat telur dihitung dari berat awal dikurangi berat setelah penyimpanan dikali 100\% (Saputra et al., 2015). Indeks bentuk telur diperoleh dari perbandingan antara lebar telur dengan panjang telur dan dinyatakan dalam persen. Tinggi albumen kental dan tinggi yolk (mm) diukur menggunakan jangka sorong. Pengukuran rongga udara dari membran dalam kerabang yang berpisah dengan membran kerabang bagian luar hingga kerabang dengan menggunakan jangka sorong (Djaelani, 2016).

\section{HASIL DAN PEMBAHASAN}

Hasil penelitian kualitas eksterior meliputi penurunan berat telur dan indeks bentuk telur tertera pada Tabel 1. Kualitas interior meliputi rongga udara, tinggi albumen dan tinggi yolk tertera pada Tabel 2.

Berat telur puyuh pada penelitian ini yaitu 9,61 gr - 11,71 gr berada pada kisaran normal. Hal ini sesuai dengan Randell dan Gery (2008); Yuwanta (2010); Parizadian et al. (2011); Hilmi et al. (2015), produktifitas burung puyuh dapat mencapai 250-300 butir/tahun dengan berat telur sekitar $8 \%$ dari bobot badan induk atau sekitar 8-11,91 gr. Berat telur puyuh dipengaruhi oleh konsumsi protein dan hormon (Latifah, 2007) serta umur (Santos et al., 2011).

Tabel 1. Kualitas eksterior telur puyuh selama penyimpanan dan temperatur yang berbeda

\begin{tabular}{|c|c|c|c|}
\hline \multicolumn{2}{|c|}{ Perlakuan } & Penurunan Berat Telur (\%) & Indeks Bentuk Telur (\%) \\
\hline \multirow{4}{*}{$\begin{array}{l}\text { Lama Penyimpanan } \\
\text { (hari) }\end{array}$} & 0 & - & 79,76 \\
\hline & 7 & $2,25^{\mathrm{a}}$ & 79,41 \\
\hline & 14 & $3,90^{\mathrm{b}}$ & 79,38 \\
\hline & 21 & $6,08^{c}$ & 74,18 \\
\hline \multirow{2}{*}{ Temperatur } & Suhu Ruang & $5,42^{\mathrm{b}}$ & 79,70 \\
\hline & Refrigerator & $2,74^{\mathrm{a}}$ & 76,66 \\
\hline \multirow{3}{*}{$p$ values } & $\begin{array}{c}\text { Lama } \\
\text { Penyimpanan }\end{array}$ & 0,0001 & 0,195 \\
\hline & Temperatur & 0,0001 & 0,274 \\
\hline & $\mathrm{L} \times \mathrm{T}$ & 0,179 & 0,352 \\
\hline
\end{tabular}

Persentase penurunan berat telur selama penyimpanan 7 hari adalah sebesar $3,42 \%$ (suhu ruang) dan $1,60 \%$ (refrigerator), penyimpanan 14 hari mengalami penurunan sebesar 6,38\% (suhu ruang) dan 2,52\% (refrigerator), penyimpanan 21 hari penurunannya sebesar $9,27 \%$ (suhu ruang) dan $4,11 \%$ (refrigerator). Jadi rata penurunan berat telur puyuh selama penyimpanan 21 hari sebesar 1,05 gr (suhu ruang) dan 0,44 gr (refrigerator).

Hasil analisis ragam menunjukkan bahwa lama penyimpanan berpengaruh nyata $(\mathrm{P}<0,05)$ terhadap penurunan berat telur puyuh. Semakin lama penyimpanan maka persentase penurunan berat telur puyuh semakin besar. Penurunan berat telur puyuh disebabkan karena pelepasan gas $\mathrm{CO}_{2}$ dan penguapan air dari dalam telur melalui pori-pori kerabang. Hal ini akan terjadi secara terus menerus selama penyimpanan sehingga makin lama telur disimpan berat telur akan semakin berkurang.

Hasil uji lanjut Duncan menunjukkan bahwa penurunan berat telur puyuh selama penyimpanan 7 hari berbeda nyata $(\mathrm{P}<0,05)$ dengan 14 hari dan 21 hari. Demikian juga penyimpanan 14 hari berbeda nyata $(\mathrm{P}<0,05)$ dengan 21 hari. Penurunan berat telur dipengaruhi oleh suhu penyimpanan, kelembaban relatif dan porositas kerabang 
telur. Pada saat penelitian temperatur penyimpanan suhu yaitu $4^{\circ} \mathrm{C}$ kelembaban $60^{\circ} \mathrm{C}$.

Rata-rata penurunan berat telur puyuh pada suhu ruang selama 21 hari adalah 9,67\% lebih tinggi jika dibandingkan dengan hasil penelitian Arifin et al. (2016) yang menunjukkan penurunan berat telur selama 3 minggu sebesar 5,48\% pada suhu ruang sekitar $27,62^{\circ} \mathrm{C}$ dengan kelembaban $58 \%$. Hasil analisis ragam menunjukkan temperatur berpengaruh nyata $(\mathrm{P}<0,05)$ terhadap berat telur puyuh. Penurunan berat telur yang berbeda diduga karena keadaan telur yang berbeda serta temperatur penyimpanan yang berbeda. Lee et al. (2016) menyatakan bahwa penyimpanan telur pada kelembaban udara yang rendah lebih cepat mengalami penurunan berat telur dibandingkan penyimpanan suhu ruang dengan kelembaban tinggi. Hal ini disebabkan oleh pengaruh kelembaban rendah akan mempercepat penguapan $\mathrm{CO}_{2}$ dan $\mathrm{H}_{2} \mathrm{O}$ dari dalam telur sehingga mempercepat penyusutan berat telur.

Masa simpan untuk telur sangatlah terbatas. Memperkecil penguapan $\mathrm{CO}_{2}$ dan $\mathrm{H}_{2} \mathrm{O}$ akan memperlambat penurunan berat telur. Oleh karena itu lama penyimpanan dan tempat penyimpanan telur harus diperhatikan. Hasil penelitian Tabidi (2011); Hilmi et al. (2015); Adamski et al. (2017) menyatakan bahwa peyimpanan telur puyuh pada suhu $3,5^{\circ} \mathrm{C}-10^{\circ} \mathrm{C}$ selama 21 hari merupakan waktu yang terbaik. Penyimpanan telur puyuh pada suhu tersebut penurunan berat telur sebesar $1,46 \%$.

Tabel 1 menunjukkan bahwa perlakuan temperatur berpengaruh tidak nyata $(\mathrm{P}>0,05)$ terhadap indeks bentuk telur. Indeks bentuk telur puyuh yaitu 79,70 (suhu ruang) dan 76,66 (refrigerator). Hasil penelitian ini juga menunjukkan bahwa perlakuan lama penyimpanan tidak berpengaruh nyata $(\mathrm{P}>0,05)$ terhadap indeks bentuk telur. Tabidi (2011) melaporkan lama simpan telur ayam tidak berpengaruh terhadap indeks bentuk telur baik itu disimpan suhu kamar maupun refrigerator.

Rata-rata indeks bentuk telur puyuh berkisar 74,18\% - 79,76\%. Dudusola (2010) menyatakan bahwa telur puyuh memiliki bentuk telur yang bulat apabila nilai indeks bentuk telur $>77$, sedangkan telur yang berbentuk ovoid (normal) memiliki nilai Shape index 69-77. Taskin et al. (2015) melaporkan indeks bentuk telur puyuh yaitu $75 \%$ - 91\%. Hasil penelitian Alawiyah (2016) melaporkan indeks bentuk telur puyuh turunan hasil persilangan warna bulu coklat dengan hitam yaitu $80,29 \%$.

Indeks bentuk telur dipengaruhi oleh periode awal bertelur dan fase produksi telur Taskin et al. (2015); Alawiyah (2016); Arifin et al. (2016) volume albumen, genetik. Semakin lebar diameter isthmus, maka bentuk telur yang dihasilkan cenderung bulat dan apabila diameter isthmus sempit, maka bentuk yang dihasilkan cenderung lonjong. Semakin tinggi nilai index telur, maka telur tersebut akan semakin bulat. Bentuk oval atau bulat pada telur dipengaruhi oleh dinding saluran telur selama pembentukan.

Hasil Analisis menunjukkan setiap perlakuan berpengaruh nyata $(\mathrm{p}<0,01)$ terhadap rongga udara. Semakin lama penyimpanan rongga udara semakin membesar. Hal ini disebabkan oleh penyusutan berat telur yang diakibatkan penguapan air dan pelepesan gas yang terjadi selama penyimpanan. Semakin bertambah umur telur, maka akan kehilangan cairan sehingga volumenya akan menyusut dan memperbesar rongga udara.

Hasil analisis ragam menunjukkan temperatur berpengaruh nyata $(\mathrm{P}<0,05)$ terhadap rongga udara telur puyuh. Rataan rongga udara telur puyuh menunjukkan lebih tinggi dibandingkan dengan hasil penelitian Imai et al. (1984) yang melaporkan bahwa penyimpanan telur puyuh selama 28 hari pada suhu $22^{\circ} \mathrm{C}$ kelembaban $54 \%$ sebesar $3,8 \mathrm{~mm}$. Perbedaan ini disebabkan karena kondisi kelembaban suhu ruangan perlakuan. Djaelani (2016) menyatakan suhu dan kelembaban merupakan salah satu faktor yang berperan dalam penurunan kualitas telur. Suhu ruang yang tinggi dengan kelembaban yang rendah mengakibatkan telur hanya mampu bertahan 14 hari. 
Tabel 2. Kualitas interior telur puyuh selama penyimpanan dan temperatur yang berbeda

\begin{tabular}{|c|c|c|c|c|}
\hline \multicolumn{2}{|c|}{ Perlakuan } & Rongga Udara (mm) & Tinggi Albumen (mm) & Tinggi Yolk (mm) \\
\hline \multirow{4}{*}{$\begin{array}{l}\text { Lama } \\
\text { Penyimpanan } \\
\text { (hari) }\end{array}$} & 0 & $0^{\mathrm{a}}$ & $4,69^{c}$ & $10,80^{\mathrm{a}}$ \\
\hline & 7 & $1,98^{\mathrm{b}}$ & $2,78^{b}$ & $6,70^{\mathrm{b}}$ \\
\hline & 14 & $3,05^{\mathrm{c}}$ & $2,89^{b}$ & $6,49^{\mathrm{b}}$ \\
\hline & 21 & $5,51^{\mathrm{d}}$ & $1,45^{\mathrm{a}}$ & $6,01^{\mathrm{b}}$ \\
\hline \multirow{2}{*}{ Temperatur } & Ruangan & $3,12^{\mathrm{b}}$ & $2,63^{\mathrm{a}}$ & $5,85^{\mathrm{a}}$ \\
\hline & Refrigerator & $2,15^{\mathrm{a}}$ & $3,27^{b}$ & $9,17^{\mathrm{b}}$ \\
\hline \multirow{3}{*}{$p$ values } & Lama penyimpanan & 0,0001 & 0,0001 & 0,0001 \\
\hline & Temperatur & 0,0001 & 0,009 & 0,0001 \\
\hline & $\mathrm{L} \times \mathrm{T}$ & 0,001 & 0,21 & 0,0001 \\
\hline
\end{tabular}

Keterangan: angka yang diikuti superskrip yang berbeda pada kolom yang sama dan perlakuan yang berbeda menunjukkan hasil yang berbeda nyata $(\mathrm{P}<0,05)$.

Jazil et al. (2013) menyatakan bahwa rongga udara terbentuk setelah peneluran akibat adanya perbedaan suhu ruang, kemudian isi telur mengkerut sehingga membran dari kerabang bagian dalam dan bagian luar. Terpisahnya membran ini terjadi pada bagian tumpul telur.
Interaksi antara lama penyimpanan dan temperatur berpengaruh nyata $(\mathrm{P}<0,05)$ terhadap rongga udara telur puyuh. Artinya semakin lama penyimpanan dan semakin tinggi suhu penyimpanan maka rongga udara akan semakin besar pula. Interaksi antara lama penyimpanan dan temperatur dapat dilihat pada Gambar 1.

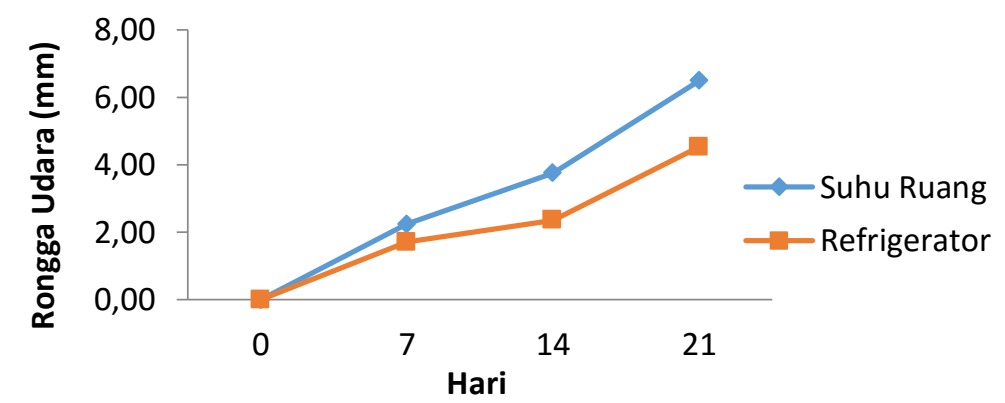

Gambar 1. Interaksi antara lama penyimpanan dan temperatur terhadap rongga udara

Tabel 2 menunjukkan lama penyimpanan berpengaruh nyata $(\mathrm{P}<0,05)$ terhadap tinggi albumen. Semakin lama penyimpanan tinggi albumen semakin rendah. Selama penyimpanan gas $\mathrm{CO}_{2}$ yang ada di dalam telur mengalami penguapan terus menerus sehingga kualitas telur menurun. Proses penguapan gas $\mathrm{CO}_{2}$ melalui pori-pori kulit dari albumen menyebabkan perubahan fisik dan kimia, sehingga albumen menjadi berair (encer). Semakin encer putih telur maka semakin rendah ketinggian putih telur. Semakin rendah ketinggian putih telur menunjukkan kualitas telur semakin menurun.

Joni et al. (2017) menyatakan penguapan $\mathrm{CO}_{2}$ mengakibatkan pengikat cairan putih telur atau ovomucin menjadi rusak. Yuwanta (2010) juga menyatakan hilangnya $\mathrm{CO}_{2}$ melalui poripori kerabang telur menyebabkan turunnya konsentrasi ion bikarbonat dalam putih telur dan menyebabkan rusaknya sistem buffer sehingga kekentalan putih telur menurun, akibatnya terjadi penurunan ketinggian albumen.

Hasil uji lanjut Duncan menunjukkan lama penyimpanan ( 7 dan 14 hari) berbeda tidak nyata $(\mathrm{P}>0,05)$ terhadap tinggi albumen. Artinya tinggi albumen selama penyimpanan 7 dan 14 tidak jauh berbeda mengakibatkan terjadinya penguapan $\mathrm{CO}_{2}$ dan $\mathrm{H}_{2} \mathrm{O}$ dari dalam telur relatif sama, sehingga tinggi albumen tidak berbeda nyata.

Penyimpanan 21 hari berbeda nyata $(\mathrm{P}<0,05)$ lebih rendah dengan perlakuan 0,7 
dan 14 hari. Rata-rata tinggi albumen pada penyimpanan 21 hari adalah $1,45 \mathrm{~mm}$. Semakin lama penyimpanan maka kekentalan albumen semakin menurun. Wilkanowska dan Kokoszynski (2012) menyatakan pengenceran albumen disebabkan karena perubahan struktur gel akibat kerusakan serabut ovomucin, sehingga $\mathrm{H}_{2} \mathrm{O}$ keluar melalui jala-jala ovomucin. Yuwanta (2010); Hegab dan Hanafy (2018) menyatakan bahwa ovomucin merupakan glikoprotein berbentuk serabut yang berperan mengikat air untuk membentuk struktur gel.

Ardiansyah (2016) menyatakan tinggi albumen dipengaruhi oleh kandungan protein didalam ransum, sehingga protein ransum mempengaruhi viskositas telur. Semakin tinggi protein ransum, maka albumen semakin kental, tinggi albumen semakin besar diameter albumen semakin sempit maka nilai indeks albumen semakin besar. Interaksi antara lama penyimpanan dengan temperatur berpengaruh tidak nyata $(\mathrm{P}>0,05)$ terhadap rongga udara.

Nilai rata-rata tinggi yolk telur puyuh pada perlakuan lama penyimpanan dan temperatur yang berbeda dapat dilihat pada Tabel 2. Lama penyimpanan berpengaruh nyata $(\mathrm{P}<0,05)$ terhadap tinggi yolk. Semakin lama penyimpanan telur puyuh maka tinggi yolk mengalami penurunan. Oksidasi pada penyimpanan yang lebih lama membuat komponen kuning telur terdegradasi sehingga tinggi yolk semakin rendah.

Hasil uji lanjut Duncan menunjukkan lama penyimpanan $(0$ hari) berbeda nyata $(\mathrm{P}<0,05)$ lebih tinggi dengan perlakuan 7, 14 dan 21 hari. Sedangkan perlakuan 7, 14 dan 21 hari tidak berbeda nyata $(\mathrm{P}>0,05)$ terhadap tinggi yolk. Artinya selama penyimpanan 7 hari hingga 21 hari, tinggi yolk relatif sama. Berdasarkan Tabel 2. Seiring lama penyimpanan terjadi penurunan tinggi yolk, hal ini disebabkan oleh penurunan elastisitas membran vitelin. Penyimpanan telur puyuh selama 21 hari pada suhu ruang tidak dianjurkan karena albumen mulai bercampur dengan yolk. Argo et al. (2013) melaporkan tinggi yolk dipengaruhi oleh membran vitelin dan lama penyimpanan. Sanchez et al. (2011) menyatakan selama penyimpanan terjadi penguapan $\mathrm{CO}_{2}$ dan $\mathrm{H}_{2} \mathrm{O}$ sehingga diameter yolk semakin besar dan tinggi yolk semakin rendah. Hanusova et al. (2016) melaporkan penurunan indeks kuning telur disebabkan oleh membran vitelin kuning telur yang tidak kuat karena air dari putih telur memasuki kuning telur secara difusi. Difusi air tersebut menyebabkan membran vitelin lemah akibat kerja enzim proteolitik sehingga kuning telur semakin encer dan diameter yolk membesar mengakibatkan yolk pecah.

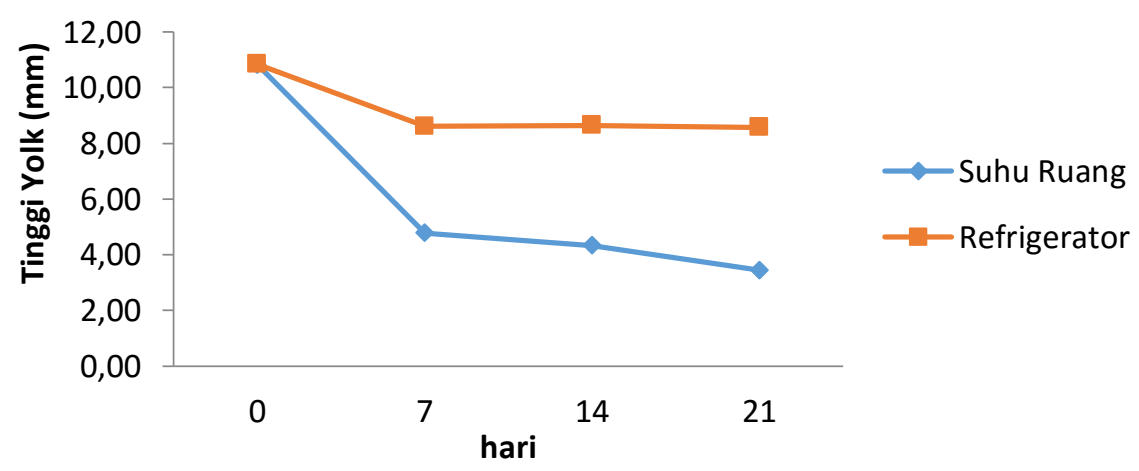

Gambar 2. Interaksi lama penyimpanan dan temperatur terhadap tinggi yolk

Hasil analisis ragam menunjukkan temperatur berpengaruh nyata $(\mathrm{P}<0,05)$ terhadap tinggi yolk telur puyuh. Interaksi antara lama penyimpanan dan temperatur berpengaruh nyata $(\mathrm{P}<0,05)$ terhadap tinggi yolk (Gambar 2). Semakin singkat lama penyimpanan dan semakin rendah temperatur penyimpanan maka semakin kental kondisi yolk telur puyuh atau semakin tinggi yolk telur.

\section{KESIMPULAN}

1. Perlakuan lama penyimpanan dan temperatur berpengaruh terhadap penurunan berat telur, rongga udara membesar, tinggi 
albumen yolk semakin rendah. Semakin lama penyimpanan dan semakin tinggi temperatur maka semakin besar rongga udara dan tinggi yolk semakin kecil.

2. Penyimpanan telur puyuh selama 21 hari pada temperatur refrigerator merupakan lama simpan terbaik terhadap kualitas telur puyuh. Lama simpan terbaik pada suhu ruang yaitu 7 hari berdasarkan penurunan berat telur puyuh yang terendah sekitar $2,25 \%$.

\section{DAFTAR PUSTAKA}

Adamski, M., J. Kuzniacka., E. Kowalska., J. K. Gaca., M. Banaszak., M. Bieniewska. 2017. Effect of storage time on the quality of japanese quail eggs (Coturnix coturnix japonica). Polish Journal of natural science 32 : 27-37

Alawiyah, I. 2016. Kualitas eksterior telur puyuh (Coturnix-coturnix japonica) turunan hasil persilangan warna bulu coklat dan hitam di pusat pembibitan puyuh universitas padjajaran. Students $e$ journals 5: 1-9

Ardiansyah, R. H. 2016. Pengaruh pemberian tingkat protein dalam ransum terhadap kualitas telur puyuh. Students e-journals 5:1-10

Argo, L. B., T. Tristiarta., I. Mangisah. 2013. Kualitas fisik telur ayam arab petelur fase I dengan berbagai level azolla microphylla. Animal Agriculture Journal 2: 445-457

Arifin, H. D., Zulfanita, and J. M. W. Wibawati. 2016. Berat telur, indeks dan volume telur puyuh (Coturnix - coturnix japonica) pengaruh konsentrasi sari markisa (Passion fruit) dan lama simpan di suhu ruang. Prosiding Seminar Nasional Sains dan Entrepreneurship III :581-587

Djaelani, M. A. 2016. Kualitas telur ayam ras (Gallus L.) setelah penyimpanan yang dilakukan pencelupan pada air mendidih dan air kapur sebelum penyimpanan. Buletin Anatomi dan Fisiologi 24:122-127.

Dudusola, I. O. 2010. Comparative evaluation of internal and external qualities of eggs from quail and guinea fowl. International Research Journal of Plant Science. 1: 112115.

Fitrah, R., D. Sudrajat., Anggraeni. 2018. Pengaruh temperatur lama penyimpanan telur puyuh tetas terhadap daya tetas, fertilitas, bobot susut telur dan bobot tetas telur puyuh. Jurnal Peternakan Nusantara 4: 25-32

Hanusova, E., C, Hrncar., A, Hanus., M, Oravcova. 2016. Egg traits in Japanese quails. Acta Fytotechn zootechn 19:62-67.

Hegab, I.M dan Hanafy, A.M. 2018. Effect of egg weight on external and internal qualities, physiological and hatching success of japanese quail eggs (Coturnix coturnix japonica). Brazilian Jounal of Poultry Science 21: 1-8

Hilmi, M., Sumiati., D.A. Astuti. 2015. Egg production and physical quality in Cortunix cortunix japonica fed diet containing piperine feed additive. Media Peternakan 38: 150-155.

Imai, C., A. Mowlah., J. Saito. 1984. Storage stability of japanese quail (Coturnix coturnix japonica) eggs at room temperature. Marketing and products 474480.

Jazil, N., A. Hintono., S. Mulyani. 2013. Penurunan kualitas telur ayam ras dengan intensitas warna coklat kerabang berbeda selama penyimpanan. Jurnal Aplikasi Teknologi Pangan 2: 43-47

Joni, I., Zulfikar dan T. Adelina. 2017. Kualitas fisik telur puyuh yang direndam dalam larutan gelatin tulang kaki ayam dengan lama penyimpanan yang berbeda. Jurnal Peternakan 14:31-41.

Latifah, R. 2007. The increasing of afkir duck's egg quality with pregnant mare's serum gonadotropin (Pmsg) hormones. The way to increase of layer duck 4:1-8.

Lee, H. M., Eun J. C., Eun. S. C., Sea H S. 2016. The effect of storage period and temperatur on egg quality in comercial eggs. Korean J. Poult Sci 43: 31-38.

Listyowati, E. 2009. Tatalaksana Budidaya Puyuh Secara Komersial. Penebar Swadaya. Jakarta

Nataamijaya, A. 2004. Fenotipe Reproduksi Dua Galur Puyuh Jepang (Coturnix coturnix japonica) pada Dua Suhu Ruangan Berbeda. JITV Vol 8: 220-226.

Parizadian, B., Y.J. Ahangari., M.S. Shargh., A. Sardarzadeh. 2011. Effect of different levels of L-carnitine supplementation on egg quality and blood parameters of laying 
japanese quail. Journal of Poultry Science 10: 621-625

Randell, M dan B. Gery. 2008. Raising japanese quail. http:www.dpi.nsw.gov.au. Diakses pada tanggal 28 November 2019.

Sanchez, Gonzalez. J.F., F.H. C. Ramirez., H. Unzon. 2011. Physicochemical changes in quail eggs (Coturnix coturnix japonica) after storage at different temperatures. Journal of Applied Animal Research 35:177-180.

Santos, T.C., A. E. Murakami., J.C. Fanhani dan C.A.L. Oliveira. 2011. Production and reproduction of egg and meat type quails reared in different group sizes. Brazilian $J$. Poultry Sci 13: 9 -14

Saputra, R., D. Septinova., T. Kurtini. 2015. Pengaruh lama penyimpanan dan warna kerabang terhadap kualitas internal telur ayam ras. Jurnal Ilmiah Peternakan Terpadu 3:75-80.

Tabidi, M. Hassan. 2011. Impact of storage period and quality on composition of table egg. Advances in Enviromental Biology 5: 856-861.

Taskin, A., U Karadavut., H. Cayan., S. Genc., I. Coskun. 2015. Determination of small variation effects of egg weight and shape index on fertility and hatching rafes in japanese quail (Coturnix coturnix japonica). Journal of Selcuk University Natural and Applied Science 4:73-83.

Wilkanowska, A and Kokoszyński D. 2012. Layer age and quality of pharaoh quail eggs. Journal of Central European Agriculture 13:10-21

Yuwanta, T. 2010. Telur dan Kualitas Telur. Gadjah Mada University Press, Yogyakarta.

Zurahmah, N. 2010. Efek Pemuasaan pada Masa Dara terhadap Pola Produksi Telur dan Distribusi Waktu Oviposisi pada Burung Puyuh. Jurnal Ilmu Peternakan 5:52-59. 